\title{
FENOMENA TABU MAKANAN \\ PADA PEREMPUAN INDONESIA \\ DALAM PERSPEKTIF ANTROPOLOGI FEMINIS
}

\author{
Tania Intan \\ Universitas Padjadjaran \\ tania.intan@unpad.ac.id
}

\section{ABSTRAK}

Fenomena tabu makanan yang dialami perempuan Indonesia berkaitan dengan dominasi kultur patriarki. Menggunakan studi dokumentasi, penelitian ini memperlihatkan bahwa dalam masyarakat penganut sistem patriarki yang kuat, tabu-tabu, termasuk tabu makanan, lebih banyak diberlakukan pada perempuan dari pada lakilaki, dan bahwa tabu makanan berkaitan dengan kepentingan untuk berbagi sumber daya makanan. Beberapa tabu makanan bertentangan dengan ajaran kesehatan, perempuan, terutama yang hamil atau menyusui, justru dilarang mengonsumsi makanan yang berprotein hewani tinggi yang diperlukan tubuh, dengan alasan kesehatan. Dampak tabu makanan menyebabkan perempuan mengalami defisit gizi yang dapat membahayakan kesehatannya. Intervensi pemerintah dan kalangan akademisi diperlukan untuk mendistribusikan kesadaran perempuan tentang urgensi dari situasi tersebut.

Kata Kunci: Tabu Makanan, Perempuan Indonesia, Perspektif Feminis, Sistem Patriarki. 


\section{ABSTRACT}

The taboo phenomenon experienced by Indonesian women involves thoughts from the field of anthropology and feminist perspectives.ndonesian women's understanding and trust in food taboos is related to the dominance of patriarchal culture. The results of the study show that in a society that adheres to a strong patriarchal system, taboos, including taboo food, are more applied to women than men, and that food taboos are related to the importance of sharing food resources. Contrary to the teachings of health, women, especially those who are pregnant or breastfeeding, are prohibited from consuming high animal protein foods that the body needs, for health reasons. The impact of taboo on food causes women to experience nutritional deficits that can endanger their health. Government intervention and academics are needed to distribute women's awareness about the urgency of the situation.

Keywords: Taboo Food, Indonesian Women, Feminist Perspective, Patriarchal Systems

\section{A. Pendahuluan}

Pola makan suatu masyarakat pada dasarnya merupakan konsep budaya yang bertalian dengan makanan, yang banyak dipengaruhi oleh unsur sosial budaya yang berlaku dalam kelompok masyarakat itu, seperti nilai sosial, norma sosial dan norma budaya bertalian dengan makanan, makanan apa yang dianggap baik dan tidak baik (Sediaoetama, 1999). Santosa dan Ranti (2004: 89) berargumentasi bahwa kebiasaan makan atau pola makan suatu masyarakat merupakan informasi yang memberi gambaran mengenai macam dan jumlah bahan makanan yang dikonsumsi setiap hari dan merupakan ciri khas untuk suatu kelompok tertentu. Hal ini juga berarti bahwa pola makan adalah cara atau perilaku 
yang ditempuh seseorang atau sekelompok orang dalam memilih, menggunakan bahan makanan dalam konsumsi pangan setiap hari yang meliputi jenis makanan, jumlah makanan, dan frekuensi makan yang berdasarkan pada faktor-faktor sosial serta budaya di tempat mereka hidup.

Dalam kajian mengenai pangan, gizi, dan kesehatan, masih banyak ditemukan permasalahan yang berhubungan dengan kepercayaan, pantangan, mitos dan tabu yang mencegah orang untuk memanfaatkan makanan yang tersedia bagi mereka (Saptandari, 2012). Mengubah kebiasaan atau pola pikir tersebut tidak mudah dilakukan, mengingat paradigma semacam ini ditanamkan sejak masa kanak-kanak. Banyak mitos yang tidak layak diyakini karena irasional, namun banyak juga di antaranya yang dapat dinalar dan masuk akal. Kepercayaan pada adanya kekuatan eksternal yang mengendalikan kehidupan membuat manusia sedapat mungkin mengatur untuk mengendalikan diri dan keluarganya agar terhindar dari marabahaya. Untuk itulah dibuat pantangan, larangan, atau tabu yang tidak lain dimaksudkan sebagai sikap moral untuk melindungi diri sendiri dari hal-hal buruk yang mungkin terjadi (Kartikowati, 2014: 160).

Menurut Humaeni (2015: 175), perempuan lebih mudah percaya pada kesakralan tabu, tepatnya bukan pada isi pantangan itu, tapi pada hikmah yang terkandung di dalam kata-kata orang tua, terutama ibu. Sejak kanakkanak, remaja, dewasa, hamil, melahirkan dan menyusui, perempuan selalu dikelilingi tabu. Di antara tahap-tahap kehidupan itu, perempuan hamil adalah yang paling cemas dan percaya tabu, karena berkaitan dengan kondisi janin dalam tubuhnya. Dalam riset Juju (2014) tentang perempuan hamil di Banten yang dikutip Humaeni (2015: 175) misalnya, dinyatakan perempuan tidak boleh makan di piring besar karena dikuatirkan sulit melahirkan. 
Perempuan yang baru melahirkan pun tidak luput dari tabu makanan. Selain dilarang makan pisang karena dikuatirkan akan keluar penis pada kelaminnya, ia juga tidak boleh makan ikan lele karena akan mengalami pendarahan.

Menurut Rodman (1988: 279), tabu atau pantangan adalah suatu pelarangan sosial yang kuat terhadap kata, benda, tindakan, atau orang yang dianggap tidak diinginkan oleh suatu kelompok, budaya, atau masyarakat. Pelanggaran tabu biasanya tidak dapat diterima dan dapat dianggap menyerang. Beberapa tindakan atau kebiasaan yang bersifat tabu bahkan dilarang secara hukum dan pelanggarannya dapat menyebabkan pemberian sanksi keras. Tabu dapat dianggap membuat malu, aib, dan perlakuan kasar dari masyarakat sekitar. Orang yang melanggar tabu pun akan mendapatkan hukuman dari masyarakat (Ahimsa-Putra, 2005).

Dari tinjauan sosiologis, Webster seperti dikutip Hasbullah (2017: 27-33), mengemukakan klasifikasi sembilan jenis tabu, yaitu: (1) tabu individual dan tabu sosial, (2) tabu kehidupan reproduksi, (3) tabu untuk perempuan, (4) tabu hubungan seksual, (5) tabu kematian dan orang yang meninggal dunia, (6) tabu orang asing, (7) tabu orang suci, raja, kepala suku, bangsawan dan tokoh agama, (8) tabu tempat-tempat sakral, (9) tabu makanan. Tabu-tabu ini memiliki banyak makna dan kegunaan bagi masyarakat yang mempercayai dan menerapkannya kehidupan mereka. Sekalipun sulit dirasionalisasikan oleh pikiran modern, masyarakat tetap meyakini, mengikuti, dan menghindari pelanggaran atas tabu-tabu karena hal itu merupakan warisan pemikiran orang tua zaman dahulu yang seharusnya memiliki hikmah. Apabila dilanggar, akan ada konsekuensi buruk yang harus ditanggung. Konsekuensi tersebut dapat berbentuk penderitaan fisik seperti kecelakaan, sakit, dan ketidakberuntungan yang 
lain, atau bisa jadi dalam bentuk psikis seperti gangguan kejiwaan, gila, stress, bahkan kematian (Webster, 1973: 53).

Salah satu tabu yang masih banyak dijumpai dalam konteks masyarakat Indonesia hingga saat ini adalah tabu makanan, yaitu larangan untuk mengonsumsi makanan tertentu karena ada beberapa ancaman atau hukuman bagi orang yang mengonsumsinya. Dalam ancaman ini, terdapat kekuatan supranatural dan mistik yang mungkin dapat menghukum mereka yang melanggar tabu ini (Susanto, 1991).

Tabu pada perempuan (women taboo) tidak hanya berlaku sejak masyarakat primitif ada tapi setelah peradaban Barat berkuasa pada masa pencerahan (Humaeni, 2015: 180). Dalam kajian-kajian komprehensif tentang tabu yang dilakukan Frazer (1890) A Study in Magic and Religion, dan Freud (1950) Totem and Taboo, dan Webster (1973) dalam Taboo: A Sociological Theory, dapat disaksikan bagaimana posisi perempuan dalam komunitas, sebagai warga kelas dua dan didominasi kaum laki-laki.

Dalam siklus kehidupan manusia, termasuk dalam proses kehamilan misalnya, memang banyak sekali mitos dan tabu makanan yang dihadapi oleh perempuan, lebih daripada yang dijalani laki-laki. Padahal sebagaimana dinyatakan Saptandari (1996), bentuk-bentuk tabu bagi perempuan hamil itu tidak selamanya kondusif bagi kesehatan, sebagai contoh; tabu untuk makan makanan tertentu acapkali menyebabkan malnutrisi bagi diri si ibu maupun bayi yang dikandungnya. Berbagai tabu yang ada itu terkadang bila dicermati, bisajadi sebenarnya merupakan rasionalisasi dari kondisi kemiskinan atau ketakutan mereka. Faktor kultur baik sosial, ekonomi, politik, dan proses budaya mempengaruhi jenis pangan apa yang dipilih orang; bagaimana mengolahnya, bagaimana cara mengonsumsinya, kapan dan di mana mereka makan dan 
sebagainya (Saptandari, 1996). Mendukung ide tersebut, Swasono (2002) berargumentasi seperti yang dikutip Angraini (2013: 168), bahwa makanan dalam pandangan sosial budaya memiliki makna yang lebih luas dari sekedar nutrisi, karena terkait dengan unsur-unsur kepercayaan, status, prestise, kesetiakawanan, dan ketentraman.

Pada konteks global, tabu makanan pada perempuan telah berlangsung sejak lama dan dengan alasan yang bervariasi. Nurti (2017: 1) menguraikan bagaimana masyarakat Papago melarang perempuan yang baru melahirkan makan garam dan gula sampai tali pusar bayi lepas (Gonzalez, 1972), dan melarang konsumsi binatang yang dianggap menjijikkan untuk melindungi bayi dari pertumbuhan fisik yang buruk (Hughes, 1963). Tabu makanan seperti ini sebenarnya merugikan perempuan dan anaknya karena membuang kesempatan mereka untuk mendapatkan zat-zat gizi yang dibutuhkan, khususnya pada masa-masa kritis. Perempuan berusia produktif juga dilarang memasukkan telur dalam menunya untuk menghindari sterilitas dan komplikasi kelahiran (HEW, 1973); ibu menyusui dilarang minum susu, dan perempuan Burma harus mengurangi makan daging dan unggas selama masa kehamilan (Mead, 1955).

Mitos, larangan dan tabu makanan yang berkaitan dengan gender dan budaya lokal memang dapat dijumpai dengan mudah di semua kebudayaan Indonesia yang didominasi ideologi patriarki (Kalangi, 1985: 42-53). Lakilaki dikonstruksikan harus perkasa, kuat secara seksual, sebaliknya perempuan dikonstruksikan untuk selalu menjaga kecantikan, kelangsingan, dan vitalitasnya untuk memuaskan kebutuhan laki-laki. Ide ini mendorong munculnya pembedaan makanan berdasarkan gender yang didasarkan pada mitos, larangan, dan tabu makanan yang berhubungan dengan seksualitas. Ada 
makanan tertentu yang dianjurkan pada laki-laki karena mitos keperkasaan sebagaimana ditemukan di Madura dan Surabaya dengan mengkonsumsi sate kambing. Ada makanan yang ditabukan bagi perempuan, seperti mentimun dan nanas karena akan membuat kelaminnya basah dan mengurangi kenikmatan bersetubuh. Banyak larangan makanan lainnya juga ditujukan pada perempuan terutama dalam kondisi hamil atau menyusui. Perempuan hamil di daerah kebudayaan Mataraman di Jawa Timur misalnya, tidak boleh makan telur karena dikuatirkan saat lahir bayinya akan mengalami bisulan di kepalanya. Dalam menyuguhkan minuman pun, secara tidak disadari terjadi pembedaan berdasarkan gender. Tanpa ditanya terlebih dahulu, biasanya tamu laki-laki akan diberi kopi dan tamu perempuan akan diberi minuman teh. Mitos, tabu, dan kepercayaan-kepercayaan yang berlaku dalam masyarakat semacam ini, dapat dikatakan sebagai bentuk pembatasan budaya terhadap kecukupan gizi. Dan pihak yang biasanya paling banyak mengalami tabu makanan semacam ini adalah kaum perempuan.

Menurut Sukandar (2007: 1), fenomena tabu makanan [pada perempuan] di Indonesia masih menjadi masalah karena banyak [jenis] makananyang seharusnya dikonsumsi tapi ternyata dihindari. Akibatnya, perempuan, terutama mereka yang sedang hamil atau menyusui, tidak berani mengonsumsi makanan tertentu yang berakibat pada status gizi mereka. Dari situasi ini, tersirat adanya permasalahan yang diasumsikan bersumber dari adanya penindasan dan ketidaksetaraan gender. Oleh karena itulah, pendekatan antropologi feminis menjadi relevan untuk membongkar praktik-praktik budaya berkaitan dengan perempuan, tepatnya seperti menurut Behar (1996) yang dikutip Jackson, S. \& Jones, J. (2009: 140), sebagai konsekuensi 
sosial dan politik dari kedudukan perempuan sebagai jenis kelamin kelas dua. Pendekatan ini membantah gagasan mengenai perilaku manusia 'alamiah' dengan menunjuk pada pola-pola budaya yang menyamarkan posisi sosial inferior perempuan (Humm, 2007: 24).

Artikel ini menjawab tiga pertanyaan riset, pertama tentang konstruksi sistem patraiarki dalam tabu makanan pada perempuan, kedua, tabu makanan dijalani oleh perempuan muda dan perempuan dewasa, perempuan hamil dan perempuan menyusui dan ketiga dampak yang mungkin terjadi akibat tabu makanan pada perempuan, dan upaya- yang mungkin dapat ditempuh untuk meminimalisasi dampak tersebut pada perempuan. Artikel ini mengumpulakn data melalui teknik dokumentasi dengan sumber data yang berasal dari penelitian-penelitian terdahulu dan sumber acuan yang relevan. Analisis terhadap sumber data menggunakan metode kualitatif dan pendekatan feminis, khususnya antropologi feminis. Idrus (2016: 2) menjelaskan bahwa antropologi feminis muncul pada kisaran tahun 1970, untuk mempertanyakan asumsi yang berpusat pada lakilaki (male centered assumptions) dalam bidang ilmu tersebut. Menurut Humm (2007: 377), riset dengan metode kualitatif merefleksikan secara lebih baik pengalaman perempuan karena penelitian jenis ini melibatkan kedekatan emosional dengan objek yang dipelajari. Perempuan dapat melihat wilayah-wilayah yang lebih sensitif seperti seksualitas atau konsep-konsep yang cukup rumit seperti kesadaran manusia. Karena penelitian ini berperspektif feminis, maka menurut Duelli Klein (1983) metodologi yang digunakan harus ditujukan untuk perempuan, bermanfaat untuk perempuan, dan memungkinkan adanya subjektivitas sadar pada perempuan dalam mempelajari perempuan 
(Humm, 2007: 285). Feminisme dalam kajian ini terutama menaruh perhatian pada hubungan kekuasaan yang tidak setara, bukan hanya pada pembedaan gender.

Penelitian-penelitian terdahulu yang menjadi acuan untuk tulisan ini dilakukan melalui studi lapangan dengan metode pengumpulan data melalui penyebaran angket dan wawancara, seperti di antaranya yang dilakukan Sukandar, seorang staf pengajar Departemen Gizi Masyarakat IPB (2006a, 2006b, 2007a, 2007b), Saptandari (2012), Angraini (2013), Kartikowati \& Hidir (2014), dan Hazbullah (2017).

\section{B. Pembahasan}

\section{Konstruksi Sistem Patriarki di Balik Tabu Makanan pada Perempuan}

Menurut penelitian Anita, (2012), para antropolog tertarik untuk mengkaji makanan karena persoalan makan dan makanan terjadi tidak hanya karena masalah fisiologis, tetapi juga karena alasan budaya. Dalam pandangan Wolf (2017:302), makananadalahsimbolutama darikesejahteraan sosial. Mereka yang dihormati oleh masyarakat, pastilah makan dengan baik. Bahkan pembagian makanan di depan umum adalah tentang menetapkan relasi-relasi kekuasaan, dan menikmatinya bersama-sama adalah tentang menyatukan kesetaraan sosial. Oleh karena itulah, menurut Wolf (2017: 303), dalam konteks mitos kecantikan, semua hal yang berhubungan dengan makan pada perempuan adalah sebuah isu publik, porsi makan (yang lebih sedikit) membenarkan dan memperkuat perasaan inferior perempuan secara sosial. Jadi ketika perempuan tidak bisa menyantap makanan yang sama dengan laki-laki, perempuan tidak mendapatkan status yang sama di dalam masyarakat. Bahkan bagi Diamond (2013: 283), pengaturan atau pelarangan terhadap makanan-makanan tertentu 
seperti ini bisa jadi berkaitan dengan konflik kepentingan dalam memperebutkan sumber daya (makanan).

Sejarah Barat mencatat bahwa diet/ pengaturan makanan yang dilakukan perempuan telah melalui perjalanan panjang. Perempuan harus selalu makan makanan yang berbeda dengan yang dimakan oleh lakilaki, lebih sedikit, dan lebih buruk. Di Prancis pada abad pertengahan, Boswell seperti dikutip Wolf (2017: 303) menunjukkan bahwa perempuan menerima sepertiga bagian dari keseluruhan gandum yang dialokasikan untuk laki-laki. Wolf (2017: 304) juga memaparkan bahwa menurut kalangan antropolog, penjelasan umum dari pembunuhan anak perempuan pada berbagai kebudayaan dipicu oleh masalah kekurangan pangan, dan pola-pola tertentu kemudian diberlakukan untuk menjamin hak-hak prioritas untuk anggota masyarakat yang 'penting', yaitu laki-laki dewasa. Secara lintas kultural juga terungkap bahwa laki-laki mendapatkan makanan panas, lebih berprotein, dan menjadi yang pertama mendapatkan piring makan. Sedangkan perempuan mendapatkan makanan sisa yang telah dingin, seringkali juga harus menggunakan tipu muslihat dan kecerdikan untuk mendapatkan cukup makanan. Selain itu, makanan yang mereka dapatkan selalu kurang bergizi.

Rosaldo dan Lamphere yang dikutip Humm (2007: 23) menegaskan bahwa semua masyarakat selalu menempatkan perempuan pada lingkup domestik dan memberikan nilai yang jauh lebih penting pada aktivitas laki-laki. Mereka berargumentasi bahwa ada hubungan langsung antara tingkat subordinasi perempuan dan bagaimana tingkat lingkup publik dan domestik dipisahkan. Pernyataan ini misalnya dibuktikan dengan situasi ibu melahirkan pada konteks budaya Jawa. Mitos 
dan tabu berbasis gender mengikuti perjalanan hidup perempuan, seperti pada prosesi penguburan ari-ari yang sebelumnya diberi garam, cabe, dan bumbu masak lainnya serta jarum dan benang dibungkus kain putih. Maknanya, bila sudah besar, si anak (perempuan) akan pandai memasak dan menjahit, sedangkan bila anak itu laki-laki, bersama ari-ari itu akan diberikan kertas, pensil, dan alat-alat tulis lainnya dengan harapan kelak jika besar nanti, ia menjadi anak yang pandai mencari ilmu dan pandai bekerja (Kartikowati, 2014: 164). Makna pemberian garam pada ari-ari sendiri dimaksudkan agar kelak anak (perempuan) tidak melupakan tugas rumah tangga dan bila anak laki-laki akan menjadi kepala rumah tangga yang tidak lupa pada asal-usulnya, sehingga bila sudah berhasil tidak menjadi orang yang sombong, sebagaimana keadaan garam yang murah dan tidak berharga.

Berbeda dengan perempuan yang menghadapi banyak tabu makanan, kaum laki-laki tidak mengalami tabu makanan secara signifikan. Laki-laki di Jeneponto, Sulawesi Selatan, misalnya hanya pantang memakan daun kelor (Sukandar, 2007b: 45). Pantangan ini karena daun itu akan membuat tubuh mereka pegal-pegal. Lakilaki di Banjar, Jawa Barat, hanya dilarang mengonsumsi jengkol dan petai karena menyebabkan rematik (Sukandar, 2006a: 55). Sedangkan di Rokan Hulu, Riau, laki-laki tidak dianjurkan makan sayap dan kepala ayam (Sukandar, 2006b: 116), karena dipercaya dapat membuat mereka ditolak perempuan saat perjodohan dan dapat membuat laki-laki menjadi pelupa. Jenis-jenis tabu makanan ini menunjukkan bahwa laki-laki pada umumnya cenderung leluasa memilih makanan yang mungkin tidak disukainya sebagai pantangan, dan bahan makanan tersebut memang tidak bergizi tinggi. Oleh karena itu, tidak ada kerugian yang besar pada pihak laki-laki bila makanan itu tidak 
disantap. Alasan pantangan pun berkelindan dengan kepentingan kesehatan mereka semata.

\section{Tabu Makanan bagi Perempuan Muda dan Dewasa, Perempuan Hamil, dan Perempuan Menyusui}

Sesuai dengan konstruksi sosial yang mengelilinginya, perempuan diharuskan untuk selalu tampil cantik, dalam arti: berkulit mulus, berambut panjang lurus, bertubuh langsing tinggi dan seterusnya. Untuk mendapatkan gambaran seperti itu, perempuan harus menahan diri termasuk menjauhi makanan yang disukainya, seperti kacang dan coklat. Kacang dan coklat menjadi tabu bagi banyak perempuan karena diyakini dapat membuat badan melebar dan wajah berjerawat (Dewi, 2009: 4). Karena takut gemuk pula, perempuan juga kerap menghindar dari konsumsi nasi dan keju (Dewi, 2009: 8). Padahal yang dituntut dari perempuan bukan hanya langsing, seperti yang dinyatakan Prabasmoro (2006: 392), ia juga harus berkulit putih, 'bersih', 'berseri', 'mulus', 'halus', 'kencang' dan sebagainya. Itulah sebabnya, perempuan pada umumnya telah terbiasa menahan keinginannya untuk makan demi menjadi 'cantik' seperti yang dituntut sekelilingnya.

Berdasarkan kajian Bertermann dari lembaga sosial Girl Effect dan Nutricion International yang dikutip Aziz (2018), kepercayaan terhadap sejumlah larangan untuk mengonsumsi makanan-makanan tertentu membuat remaja putri Indonesia mengalami kekurangan gizi hingga menghambat pertumbuhannya. Alih-alih menikmati makanan sehat, mereka cenderung memakan kudapan dan fast food. Remaja putri yang disurvey Bertermann mengaku menghindari mentimun karena dianggap menyebabkan keputihan, dan nanas yang dapat membuat mereka sulit 
hamil kelak. Penelitian keadaan nutrisi remaja putri berumur 13-18 tahun tersebut dilakukan pada tahun 2017, di antaranya di daerah Lombok. Para peneliti menemukan $10 \%$ remaja terlalu kurus atau indeks massa tubuhnya rendah, sementara 10\% lainnya justru mengalami kelebihan berat badan.

Dalam penelitian Sukandar (2006a: 55), diketahui bahwa di Banjar, Jawa Barat, makanan tabu bagi perempuan dewasa cukup banyak yaitu ada 16 macam makanan. Nanas, pisang ambon, dan daun singkong adalah makanan yang paling sering disebutkan sebagai makanan tabu bagi perempuan dewasa.

Seentara tabu makanan di Barito Kalimantan Selatan, Sukandar (2007a: 47),mencatat dua macam makanan yang terlarang bagi perempuan dewasa, yaitu telur dan pisang kembar. Menurut kepercayaan setempat, pisang kembar dapat menyebabkan ibu melahirkan bayi kembar dempet. Kepatuhan untuk menghormati larangan ini sebenarnya sangat merugikan perempuan dewasa karena untuk kesehatannya, mereka sebenarnya perlu mengonsumsi telur yang mengandung protein yang tinggi dan terjangkau harganya. Sedangkan pada risetnya di Jeneponto, Sulawesi Selatan, Sukandar (2007b: 45) menemukan bahwa makanan tabu yang utama bagi perempuan di wilayah tersebut adalah buah mangga dan berbagai jenis ikan. Mangga harus dijauhi perempuan karena dipercaya dapat menyebabkan bau badan dan haid yang tidak berhenti. Sedangkan berbagai macam ikan seperti balle-balle, balana, hiu, dan ciko pantang dikonsumsi dengan alasan sumpah nenek moyang untuk tidak memakannya karena mereka pernah ditolong oleh ikan-ikan tersebut. Jika ada perempuan yang tidak patuh dan memakannya, ia akan menderita penyakit kulit. Jayati, L.D, Madanijah, S. \& Khomsan A. (2016: 36) menyatakan bahwa di wilayah Kasepuhan Ciptagelar, 
Jawa Barat, makanan yang tabu dimakan oleh perempuan adalah pisang ambon, ikan dan kerang yang memengaruhi densitas asupan protein.

Perempuan yang mendapatkan tabu makanan berikunya adalah Perempuan hamil. Kehamilan dipandang sebagai peristiwa publik. Satu-satunya peristiwa pribadi dalam suatu kehamilan adalah bahwajanin tumbuh di suatu tubuh subjek perempuan. Bahkan karena visibilitasnya, subjek hamil sesungguhnya tidak dapat menyembunyikan proses di dalam tubuhnya itu. Dengan demikian, kehamilan sangat berpotensi menjadi ruang ketika semua orang merasa dapat berpartisipasi dan mempunyai hak atas kehamilan itu. Kehamilan memublikkan subjek hamil (Priyatna, 2005).

Campur tangan orang tua dan suami sangat jelas menjadi sumber dari pantangan-pantangan makan bagi perempuan hamil. Tabu makanan yang dipercaya perempuan hamil, menurut Rofi' ah, S.K dkk. (2017:3) dapat memengaruhi pemilihan makanan sebagai bentuk asupan nutrisinya. Berbagai jenis makanan memang dianjurkan dikonsumsi untuk memperlancar proses kehamilan dan persalinannya. Namun, ibu hamil juga harus melakukan pemilihan dan pantang makanan tertentu karena ingin menghormati anjuran orang tua (ibu atau ibu mertua) dan untuk menghindari berbagai konflik yang dapat timbul nantinya. Munculnya pandangan tentang makanan yang boleh atau tidak boleh dimakan seperti ini menimbulkan kategori "bukan makanan" sebagai sebutan makanan yang tidak boleh dimakan (Anderson, 2006: 313).

Pasangan yang ingin mendapatkan keturunan pun misalnya sering ditakut-takuti untuk tidak mengonsumsi kedelai dan produk turunannya seperti tahu dan tempe yang dianggap membuat alat reproduksi tidak subur (Dewi, 2009: 3). Perempuan hamil juga tidak boleh memakan telur 
(Dewi, 2009: 6) karena dikhawatirkan ASInya nanti berbau amis. Perempuan yang sedang mengandung juga pantang memakan ikan laut, karena dapat membuat ASI menjadi bau amis dan menyebabkan luka jahit sisa persalinan menjadi sulit kering.

Menurut Fannania (2017), ada tujuh jenis makanan yang dilarang untuk dikonsumsi perempuan hamil, yaitu: (1) gurita, karena diyakini janin akan terbelit ariari ketika dilahirkan dan juga akan mengakibatkan penyakit gatal pada ibu dan janinnya, (2) ikan hiu, yang dapat mengakibatkan janin sulit keluar dan akan terjadi perdarahan saat melahirkan, (3) ikan yang dapat menyebabkan bau badan ibu dan janin dalam kandungan menjadi amis, (4) udang yang masih dipercaya dapat membuat anak yang dilahirkan menjadi bungkuk. Budaya tabu lainnya adalah bila ibu hamil mengonsumsi (5) jantung pisang, bentuk kepala bayi akan menjadi lonjong seperti jantung pisang. (6) Salak juga tidak dianjurkan untuk dikonsumsi karena menyebabkan perempuan susah buang air besar. Sedangkan buah (7) durian dan nanas dipercaya akan menyebabkan keguguran dan juga menurut Dewi (2009: 5) dianggap membuat kelamin perempuan 'becek' dan mengalami keputihan.

Penelitian yang dilakukan Sukandar (2007a: 46) mengungkapkan bahwa tabu makanan pada perempuan hamil sebenarnya berkaitan dengan [ketakutan pada] kelahiran yang sulit, menyakitkan, atau menyebabkan keguguran. Ada tujuh jenis makanan yang dihindari untuk dikonsumsi perempuan daerah Barito Kalimantan Selatan, yaitu: es, pisang kembar, kelapa muda, air kelapa, nenas muda, ikan, dan ikan tauman. Pada penelitian lainnya dengan tema serupa di Jeneponto Sulawesi Selatan, Sukandar (2007b: 44) menemukan jumlah tabu makanan yang lebih banyak, yang terdiri dari tumbuhan seperti 
buah tala, daun kelor, terong; dan sejumlah ikan seperti pari, toka-toka, gurita dan cumi-cumi. Makanan yang ditabukan bagi ibu hamil memang sangat banyak dan alasan yang diberikan oleh responden tidak selalu masuk akal masyarakat umum. Sebagai contoh, pepaya ditabukan karena akan menyebabkan bayinya susah keluar, anak dalam perut akan sakit, akan terasa sakit waktu melahirkan, dan lain-lain. Cumi-cumi, ikan pari dan ikan toka-toka sebenarnya sangat baik bagi perempuan hamil karena merupakan sumber protein yang tinggi.

Pada penelitiannya di Banjar, Jawa Barat, Sukandar (2006a: 53) menemukan 35 jenis makanan yang tidak boleh dikonsumsi perempuan hamil, termasuk di antaranya adalah lele, belut, ikan gabus, dan udang yang berprotein tinggi. Selain itu, daun melinjo juga ditabukan karena dianggap dapat menyebabkan darah bau, sulit melahirkan, gatal dan dapat ketiduran saat perempuan itu melahirkan.

Hasil penelitian-penelitian yang dilakukan Sukandar ini tidak bertentangan dengan kajian Rofi'ah dkk (2017: 7) di Pucakwangi, Pati Jawa Tengah, yang menemukan bahwa perempuan hamil pada umumnya memang ditabukan mengonsumsi berbagai jenis ikan, udang dan kerang, juga buah-buahan seperti kurma, salak, anggur, durian, dan papaya. Informasi tentang larangan-larangan ini menurutnya didapatkan sebagian besar dari orang tua, bidan, dan internet.

Penelitian lainnya yang dilakukan Kartikowati (2014: 164) mengungkapkan tentang mitos berkaitan dengan makanan yang tumbuh dalam masyarakat Melayu di wilayah Kuantan. Selama berada dalam proses kehamilan, perempuan tidak boleh banyak makan nenas, tidak boleh banyak minum es karena dikhawatirkan anak bayi membesar sehingga sulit saat persalinan. Pada masa kehamilan, perempuan hamil pantang makan makanan 
yang pedas, karena diperkirakan dapat berpengaruh pada kondisi bayinya. Makanan lain yang dipantang adalah makan nangka (gulai) karena perut bayi akan kembung. Perempuan hamil tidak boleh banyak makan telur, ditakutkan janin di dalam perutnya akan mengalami bisul. Hal ini bisa jadi ada benarnya karena telur banyak mengandung albumen.

Fase Kehidupan selanjutnya bagi perempuan yang berkaitan dengan tabu makanan adalah masa menyusui. Angraini (2013: 177) menyatakan bahwa perempuan menyusui di Jombang justru didukung untuk mengonsumsi makanan-makanan tertentu yang mengandung makna simbolik di baliknya, dan tidak selalu untuk alasan kesehatan. Mereka makan sayur bayam agar hidupnya bisa adem ayem; kecambah agar tidak cepat menambah anak lagi, telur yang merupakan simbol wiji aji artinya lahir dari rahim ibunya dan menjadi harapan orang tua agar bisa membanggakan; kangkung agar anak yang dilahirkan menjadi lebih tangguh dalam menjalani hidup; ikan asin yang merupakan simbol tidak boleh membunuh hewan; belut agar kelahiran bayi lancar selicin belut, kepala ayam sebagai simbol kemudahan dalam menjalankan kehidupan dan derajat tinggi. Dipercaya jika ibu hamil rajin mengkonsumsi kepala ayam maka kelak anaknya selalu mendapat derajat yang tinggi dalam lingkungannya; dan kunyit (kunir) yang akan membuat bayi lahir dalam keadaan bersih tidak berbintik-bintik hitam pada tubuhnya.

Menurut Sukandar (2007a: 46), berdasarkan survey yang dilakukannya di Barito, makanan yang ditabukan bagi ibu menyusui setidaknya ada 11 jenis, termasuk telur dan ikan. Sedangkan dari hasil penelitiannya di Jeneponto, Sulawesi Selatan, Sukandar (2007b: 45) menemukan bahwa tabu makanan pada perempuan menyusui yang terpenting adalah cabe rawit, yang dipercaya dapat menyebabkan 
bayi mencret dan pantatnya menjadi berwarna merah. Selain itu, sumber protein tinggi seperti ayam, ikan, dan udang juga harus dijauhi, karena masyarakat di daerah itu percaya anak dapat mengalami bau badan yang busuk, lumpuh, atau sakit cacar. Di daerah Jawa Barat, perempuan menyusui juga meyakini bahwa lalapan lebih baik untuk dikonsumsi daripada ikan, daging sapi dan ayam, karena ASI mereka terbukti menjadi lebih banyak secara kuantitas, dan jika memakan makanan dari golongan hewani tersebut dapat menyebabkan rasa ASI menjadi amis, badan gatal dan sulit melahirkan. Tanpa sadar, mereka mengabaikan kualitas ASI sendiri, dan karena tubuhnya kekurangan protein hewani, perempuan Sunda banyak yang mengalami anemia (Angraini, 2013: 170).

Penelitian Sukandar (2006a: 53) yang dilakukannya di Banjar, Jawa Barat, menunjukkan ada 23 jenis makanan yang ditabukan bagi perempuan menyusui. Keluwih, nangka, labu kuning, makanan panas, makanan pedas, dan labu adalah makanan yang paling sering disebutkan oleh responden. Alasan yang mereka berikan tidak logis, sebagai contoh keluwih, yang ditabukan dengan banyak alasan misalnya menyebabkan cepat punya anak lagi, ASI kurang, perut kembung, bicara tidak lancar dan sebagainya. Telur dan ikan yang sebenarnya sangat baik bagi ibu menyusui karena merupakan sumber protein juga ditabukan.

\section{Dampak Tabu Makanan pada Kondisi Kesehatan Perempuan dan Upaya-upaya untuk Mengatasinya}

Ada beberapa penjelasan logis tentang larangan memakan beberapa jenis bahan pangan. Salah satu di antaranya adalah karena makanan-makanan tertentu mengandung zat alergen yang berpotensi memicu alergi khususnya pada perempuan hamil dan janin yang 
dikandungnya(Fannania, 2017). Namun demikian, menurut Nurbaiti, L. et al. (2014: 111) akibat tabu makanan yang melarang perempuan hamil atau perempuan menyusui di Lombok Tengah mengonsumsi beberapa bahan makanan kaya protein, serat, dan nutrisi, kepercayaan yang bertentangan dengan prinsip-prinsip gizi ini terusmenerus dipraktikkan. Ikan dan cumi yang tabu bagi ibu hamil, sebenarnya adalah bahan makanan tinggi protein dan zinc yang sangat baik dalam pembentukan tulang panjang dan peningkatan daya tahan tubuh. Kualitas ASI yang tidak memadai dan pengetahuan yang minim tentang gizi keluarga pada sebagian perempuan suku Sasak menyebabkan perkembangan anak tidak optimal, dan bahkan menyebabkan stunting atau kependekan anak intergenerasi. Dampak jangka panjang stunting adalah terjadinya kependekan anak intergenerasi. Menurut Keefe et al. (2008) yang dikutip Nurbaiti (2014: 105), pada anak perempuan, dampaknya akan terlihat ketika dewasa atau hamil. Perempuan yang stunting berisiko lebih tinggi mengalami retardasi atau perlambatan pertumbuhan pada janinnya (intra uterine growth retardation/IUGR) serta melahirkan bayi dengan berat badan lahir rendah (BBLR). Tubuh yang pendek secara psikologis juga mempengaruhi self-esteem seorang anak dalam kehidupan sosialnya, terutama saat menginjak masa remaja.

Buah-buahan yang menjadi tabu makanan bagi perempuan dalam hampir setiap kebudayaan adalah pisang dan nanas, yang sebenarnya tidak berbahaya karena justru dapat memperlancar proses pencernaan. Vitamin C dan Kalium yang terdapat di dalamnya menjaga daya tahan dan menahan cairan tubuh. Perempuan hamil yang memang sensitif lambungnya, memang tidak dianjurkan untuk memakan nanas dalam jumlah banyak, tapi hal ini tidak berarti dilarang total. 
Mengonsumsi ikan laut juga sangat baik, karena alih-alih menyebabkan luka menjadi lama kering, justru membantu mengganti jaringan tubuh yang rusak saat persalinan (Dewi, 2009: 7). Ikan juga mengandung Omega 3, vitamin, mineral, dan asam amino tinggi yang penting untuk kesehatan dan perkembangan sel-sel otak. Perempuan menyusui, selain ditabukan mengonsumsi ikan, juga tidak dianjurkan menyantap telur, padahal kedua bahan makanan ini sangat baik untuk karena merupakan sumber protein. Pantangan ini tentunya akan mempengaruhi asupan gizi jika ibu menyusui tersebut menurut begitu saja pada tabu yang telah ditetapkan. Pawitri (2018) menyarankan agar ibu menyusui memilih ikan yang segar dan memastikan sumber air yang menjadi tempat hidupikan itu tidak tercemar logam berat berbahaya. Sedangkan cabe memang tidak baik bila dikonsumsi terlalu banyak, bukan karena berpengaruh pada ASI, namun dapat membuat ibu menyusui mengalami diare sehingga berdampak pada perawatan bayinya.

Dari seluruh pembahasan ini, timbul pendapat bahwa penerapan tabu makanan pada perempuan cenderung merugikan perempuan dan sebaliknya menguntungkan laki-laki. Tabu menjadi semacam penanda otoritas lakilaki atas diri perempuan, sehingga perempuan dibatasi oleh pantangan-pantangan yang membuatnya tidak leluasa beraktivitas dalam kegiatan yang didominasi lakilaki (Handayani, 2002: 11-12). Bila tabu dianggap sebagai perlindungan atau demi untuk kebaikan perempuan, maka dapat pula diartikan bahwa perempuan adalah memang mahluk yang lemah yang membutuhkan banyak perlindungan (Humaeni, 2015). Kondisi perempuan yang menerima tabu makanan sebagai bagian dari pola kehidupannya dapat diargumentasikan sebagai perilaku tidak berdaya perempuan dalam menolak konstruksi 
patriarki. Sekalipun perempuan memahami pentingnya zat-zat gisi yang justru dijauhkan dari menu sehari-hari mereka, perempuan tidak selalu dapat menuntut pada lingkungannya untuk mendapat hak makan yang sama dengan laki-laki.

Dalam semangat pengarusutamaan gagasan tentang kesetaraan gender di Indonesia dan urgensi dari masalah pelik ini, tampaknya diperlukan upaya-upaya nyata untuk mengatasi permasalahan tabu makanan pada perempuan, terlebih bila fenomena itu menjadi penyebab kondisi malnutrisi pada ibu dan anak. Berbagai langkah dapat dilakukan oleh berbagai pihak terutama kalangan pemerintah bekerja sama dengan akademisi di bidang kesehatan, gizi, budaya, dan praktisi gender. Langkah termudah dapat dilakukan dari keluarga sebagai unit sosial terkecil, yang harus mempertimbangkan kembali rasionalitas dan manfaat penerapan tabu makanan bagi anggota keluarganya.

Agar situasi ini tidak terus-menerus merugikan kaum perempuan, diperlukan adanya sosialisasi pendidikan yang tepat tentang gizi maupun kebijakan-kebijakan yang disusun dengan berpihak pada perempuan. Intervensi pemerintah dan kalangan akademisi harus hadir untuk mendistribusikan kesadaran dari berbagai pihak tentang urgensi situasi tersebut. Namun demikian di atas semua itu, perempuan sendiri yang seharusnya mampu memilih dan memilah dengan akal sehatnya, dalam mengonsumsi makanan-makanan yang disebut 'terlarang' baginya itu secara bijak dan moderat. Suatu langkah besar harus dilakukan, untuk membongkar paradigma seperti yang dinyatakan Wolf (2017: 306), bahwa “[...] perempuan [pada umumnya] merasa tidak berhak untuk mendapatkan cukup makanan karena sejak lahir mereka telah diajarkan untuk mendapatkan lebih sedikit daripada yang 
diperlukan, dalam sebuah tradiri turun temurun melalui garis keturunan ibu, yang tidak ada ujungnya."

\section{Simpulan}

Penelitian ini memperlihatkan bahwa dalam masyarakat penganut sistem patriarki yang kuat, tabutabu, termasuk tabu makanan, terbukti lebih banyak diberlakukan pada perempuan daripada laki-laki, dan bahwa tabu makanan berkaitan dengan kepentingan untuk berbagi sumber daya makanan. Bertentangan dengan ajaran kesehatan, perempuan, terutama yang hamil atau menyusui, justru dilarang mengonsumsi makanan dari golongan hewani seperti cumi-cumi, udang, kepiting, daging kambing, telur bebek dan ikan; dari golongan nabati seperti jantung pisang, rebung, kemangi, dan terong; dan dari golongan buah-buahan seperti nangka, nanas, durian, dan pisang, dengan alasan kesehatan pula.

Dampak tabu makanan pada kenyataannya menyebabkan perempuan mengalami defisit gizi yang dapat membahayakan tubuhnya. Pandangan masyarakat Indonesia tentang tabu makanan yang merugikan perempuan masih kuat karena dilanggengkan dengan cara diturunkan dari satu generasi ke generasi berikutnya. Padahal kenyataannya, [hampir] seluruh bahan makanan itu baik dan diperlukan oleh tubuh perempuan, seperti yang telah diuji secara empiris, sehingga tidak seharusnya dihindari sama sekali. Perempuan, terutama mereka yang hamil dan menyusui, tidak [selalu] memiliki kuasa untuk menolak tabu makanan ini terutama karena ingin menghindari konflik dengan lingkungan sekitarnya, dan juga karena berkaitan dengan kecemasan pada kondisi kesehatan (calon) bayinya. 


\section{DAFTAR PUSTAKA}

Ahimsa-Putra, H. S, 2005, Masalah Kesehatan dalam kajian Ilmu Sosial Budaya, Yogyakarta: KEPEL-Press.

Anderson, F. d, 2006, Antropologi Kesehatan, UI-Press: Jakarta.

Angraini, D, 2013," Pantangan Makan Ibu Hamil dan Pasca Melahirkan di Desa Bongkot Kecamatan Peterongan Kabupaten Jombang" dalam Jurnal Biokultur, Vol. II No. 2 hal. 167-178.

Anita, S. B, 2012," Kuliner dan Konstruksi Identitas Kelokalan Studi Kasus Tentang Pempek Bagi "Wong Kito" di Kota Palembang", Tesis (S2), Universitas Gadjah Mada, Yogyakarta.

Aziz, N. 2018, "Nanas dan Mentimun Sebabkan Remaja Putri Indonesia Kurang Gizi?". dalam BBC News Indonesia 15 Juni 2018

Dewi, R. D. K, 2009, “Pandangan Masyarakat mengenai Makanan Pantangan yang Justru adalah Makanan Bergizi." dalam https://rizqidyan.wordpress. com/2012/10/11/pandangan-masyarakatmengenai-makanan-pantangan-yang-justru-adalahmakanan-bergizi/

Diamond, J, 2013, The World Until Yesterday: What can we learn from traditional societies?, London: Penguin.

Fannania, 2017, “7 Budaya Tabu Makanan pada Masa Kehamilan" dalam Brilio. https://www.brilio. net/creator/7-budaya-tabu-makanan-pada-masakehamilan-111735.html.

Handayani, T. S, 2002, Konsep dan Teknik Penelitian Gender, Malang: UMM Press.

Hasbullah, A, 2017, “Makna Tabu-Tabu pada Kaum Perempuan 
Sunda (Studi Desa Kodasari Kecamatan Ligung Kabupaten Majalengka), (Skripsi S

1), Institut Agama Islam Negeri Raden Intan, Lampung.

Humaeni, A, 2015, " Tabu Perempuan dalam Masyarakat Banten" dalam Jurnal Humaniora Vol. 27 No. 2, 174185.

Humm, M, 2007, Ensiklopedia Feminisme (M. Rahayu, Trans.), Yogyakarta: Fajar Pustaka Baru.

Idrus, N. I, 2016," Antropologi Feminis: Etnografi, Relasi Gender dan Relativisme Budaya di Indonesia" Pidato Pengukuhan Guru Besar Tetap bidang Ilmu Antropologi. Makasar: Universitas Hasanuddin.

Jackson, S. J., J. 2009, Pengantar Teori-teori Feminis Kontemporer, Yogyakarta: Jalasutra.

Jayati, L. D., Madanijah, S. \& Khomsan A, 2016, "Pola Konsumsi Pangan, Kebiasaan Makan, dan Densitas Gizi pada Masyarakat Kasepuhan Ciptagelar Jawa Barat", dalam Jurnal Penelitian Gizi Makan Vol. 37 No. $133-42$.

Kalangi, N. S, 1985, "Makanan sebagai Suatu Sistem Budaya: Beberapa Pokok Perhatian Antropologi Gizi" dalam K. d. A. Loedin (Ed.), Ilmu-Ilmu Sosial dalam Pembangunan Kesehatan. Jakarta: PT Gramedia.

Kartikowati, S. H., Achmad, 2014, "Sistem Kepercayaan Di Kalangan Ibu Hamil Dalam Masyarakat Melayu" dalam Jurnal PARALLELA, Vol. 1 No.2, 89-167.

Nurbaiti, L. e. a, 2014, “Kebiasaan Makan Balita Stunting pada Masyarakat Suku Sasak: Tinjauan 1000 Hari Pertama Kehidupan (HPK)" dalam Jurnal MASYARAKAT, KEBUDAYAAN DAN POLITIK, Vol. 27 No. 2, hal. 104-112. 
Nurti, Y, 2017, “Kajian Makanan dalam Perspektif Antropologi". dalam Jurnal ANTROPOLOGI: Isu-Isu Sosial Budaya Vol.19 No. 1 hal. 1-10.

Pawitri, R, 2018, “Fakta dan Mitos Makanan Ibu Menyusui" tersedia seacra online dalam https:// id.theasianparent.com/fakta-dan-mitos-makananibu-menyusui/

Prabasmoro, A. P, 2006, Kajian Budaya Feminis : tubuh, sastra, dan budaya pop. Yogyakarta: Jalasutra.

Priyatna, A, 2005, 20Oktober 2005, Hamil, Pikiran Rakyat.

Rodman, R, 1988, An Introduction to Language. New York: The Dryden Press.

Rofi' ah, S. K. d, 2017, “Perilaku Kesehatan Ibu Hamil dalam Pemilihan Makanan di Kecamatan Pucakwangi Kabupaten Pati" dalam Jurnal SOLIDARITY, Vol. 6 No. 2.

Santoso, S. d. R., S, 2004, Kesehatan dan Gizi. Jakarta: Rineka Cipta.

Saptandari, P, 1996, "Gender dan Masalah Kesehatan Wanita" dalam S. Bagong, Emmy Susanti (Ed.), Wanita dari Subordinasi dan Marjinalisasi menuju ke Pemberdayaan, Surabaya: Airlangga University Press.

Saptandari, P, 2012. “Faktor Sosial Budaya dalam Masalah Kesehatan dan Gizi di Jawa Timur" dalam. http:// pinky_saptandari-fisip.web.unair.ac.id/artikel_ detail-67565-antropologi\%20kesehatan-Gizi $\% 20$ \&\%20Budaya.html.

Sediaoetama, A. D, 1999. "Ilmu Gizi untuk Mahasiswa dan Profesi di Indonesia. Jakarta: PT Dian Rakyat"

Sukandar, D, 2006a, " Makanan Tabu di Banjar Jawa Barat" dalam Jurnal GIZI DAN PANGAN Vol. 1 No.1 51-56. 
Sukandar, D, 2006b, "Makanan Tabu di Rokan Hulu Riau” dalam Jurnal GIZI DAN PANGAN, 113-117.

Sukandar, D, 2007a. "Makanan Tabu di Barito Kuala Kalimantan Selatan" dalam Jurnal GIZI DAN PANGAN, Vol.2 No.2, 44-48.

Sukandar, D, 2007b “ Makanan Tabu di Jeneponto Sulawesi Selatan" dalam Jurnal GIZI DAN PANGAN Vol. 2 No. 1, 42-46.

Susanto, D, 1991, "Fungsi-fungsi Sosio-Budaya Makanan" dalam Jurnal Pangan Vol. 9, 51-56.

Webster, H, 1973, Taboo: A Sociological Study. New York: Octagon Books.

Wolf, N, 2017, Mitos Kecantikan: Menafsir Kecantikan dalam Berbagai Konteks (A. S. Witakania Sundasari, Trans. L. M. Rahayu Ed.), Bandung: Unpad Press. 